\title{
Curcumin suppresses HIF1A synthesis and VEGFA release in pituitary adenomas
}

\author{
B Shan, C Schaaf, A Schmidt, K Lucia, M Buchfelder ${ }^{1}$, M Losa ${ }^{2}$, D Kuhlen ${ }^{3}$, J Kreutzer ${ }^{3}$, M J Perone ${ }^{4,5}$, \\ E Arzt ${ }^{4,5}$, G K Stalla and U Renner
}

Neuroendocrinology Group, Max Planck Institute of Psychiatry, Kraepelinstraße 10, D-80804 Munich, Germany

${ }^{1}$ Department of Neurosurgery, University of Erlangen-Nuremburg, Schwabachanlage 6, 91594 Erlangen, Germany

${ }^{2}$ Department of Neurosurgery, Istituto San Raffaele, Via Olgettina 60, 20132 Milano, Italy

${ }^{3}$ Department of Neurosurgery, Technical University Munich, Ismaninger Straße 22, 81675 Munich, Germany

${ }^{4}$ Laboratorio de Fisiología y Biología Molecular, Departamento de Fisiología y Biología Molecular y Celular, Facultad de Ciencias Exactas y Naturales, Universidad de Buenos Aires, Buenos Aires, Argentina

${ }^{5}$ IBioBA-CONICET, Max Planck Partner Institute, RA-1428 Buenos Aires, Argentina

(Correspondence should be addressed to U Renner; Email: renner@mpipsykl.mpg.de)

\begin{abstract}
Curcumin (diferuloylmethane), a polyphenolic compound derived from the spice plant Curcuma longa, displays multiple actions on solid tumours including anti-angiogenic effects. Here we have studied in rodent and human pituitary tumour cells the influence of curcumin on the production of hypoxia inducible factor $1 \alpha$ (HIF1A) and vascular endothelial growth factor A (VEGFA), two key components involved in tumour neovascularisation through angiogenesis. Curcumin dose-dependently inhibited basal VEGFA secretion in corticotroph AtT20 mouse and lactosomatotroph GH3 rat pituitary tumour cells as well as in all human pituitary adenoma cell cultures $(n=32)$ studied. Under hypoxia-mimicking conditions $\left(\mathrm{CoCl}_{2}\right.$ treatment) in
\end{abstract}

AtT20 and GH3 cells as well as in all human pituitary adenoma cell cultures $(n=8)$ studied, curcumin strongly suppressed the induction of mRNA synthesis and protein production of HIF1A, the regulated subunit of the hypoxia-induced transcription factor HIF1. Curcumin also blocked hypoxiainduced mRNA synthesis and secretion of VEGFA in GH3 cells and in all human pituitary adenoma cell cultures investigated $(n=18)$. Thus, curcumin may inhibit pituitary adenoma progression not only through previously demonstrated antiproliferative and pro-apoptotic actions but also by its suppressive effects on pituitary tumour neovascularisation.

Journal of Endocrinology (2012) 214, 389-398

\section{Introduction}

In addition to substances such as taxol and vincristine, which are already used for chemotherapy of different types of cancer, a growing number of other herbal compounds with putative chemotherapeutic properties have been detected in the past decades (Gupta et al. 2010). One of these substances is curcumin, the active ingredient of the spice plant Curcuma longa. Curcumin (diferuloylmethane) belongs to the group of polyphenolic herbal compounds and has multiple beneficial effects including anti-tumourigenic actions in different types of human cancers, in particular in tumours of the gastrointestinal tract (Kunnumakkara et al. 2008). Although the efficacy of curcumin is currently under investigation in several clinical trials, its usage is limited by its poor bioavailability, which is due to very rapid renal excretion and hepatic degradation (Shehzad et al. 2010). More stable curcumin derivatives or curcumin-releasing microparticles, which have successfully been applied in recent studies
(Thomas et al. 2008, Shahani et al. 2010), may overcome this problem in the future.

Tumours of the anterior pituitary represent the second most frequent type of intracranial neoplasms and are mostly benign adenomas derived by monoclonal expansion from transformed hormone- or non-hormone-producing pituitary cells (Asa \& Ezzat 2009, Melmed 2011). Clinical symptoms are caused by mass effects of the tumours (headache, visual field loss, etc.) and/or by hyper-secretion of hormones (Asa \& Ezzat 2009, Melmed 2011, Perez-Castro et al. 2012). Prolactinomas are the most abundant type of pituitary tumours $(40-50 \%$ of all) followed by endocrine-inactive adenomas (20-25\%), somatotropinomas (20\%) and corticotropinomas (4-8\%) (Asa \& Ezzat 2009, Melmed 2011). Thyrotropinomas $(<1 \%)$, gonadotropinomas $(<1 \%)$ and pituitary carcinomas $(<0 \cdot 1 \%)$ are rare entities of pituitary tumours (Saeger et al. 2007). Medical treatment regimens with dopamine agonists and somatostatin analogues are established for prolactinomas and somatotropinomas 
respectively (Colao \& Savastano 2011, Giustina et al. 2011), and promising treatment results with temozolomide have been reported in a few cases of pituitary carcinoma (Raverot et al. 2010). The other pituitary adenoma types as well as drug-resistant prolactinomas and somatotropinomas have to be removed by transsphenoidal or transcranial surgery. However, if critically localised, the tumours cannot be completely removed and start to re-grow. Thus, alternative options for the pharmacological treatment of pituitary adenomas are needed.

Like any type of solid tumours, expanding pituitary adenomas develop an intratumoural vascular network, which is necessary to transport oxygen and nutrients to the tumour cells and to remove intratumoural waste products (Turner et al. 2000, Carmeliet 2003). Tumour neovascularisation is induced by intratumoural hypoxia, which leads to an increase in hypoxia inducible factor $1 \alpha$ (HIF1A), the regulated subunit of the transcription factor HIF1 (Harris 2002, Hickey \& Simon 2006). The latter is composed of two subunits, the constitutively expressed HIF1B and HIF1A, which is absent under normoxic conditions but is rapidly up-regulated under hypoxia (Webb et al. 2009) and stabilised in pituitary tumour cells by RSUME (Carbia-Nagashima et al. 2007, Shan et al. 2012). HIF1 regulates multiple genes to induce mechanisms to overcome cellular hypoxia; among them angiogenesis, a complex process in which multiple angiogenic factors induce, in a coordinated manner, the sprouting of new vessels from already existing ones and direct their growth into the expanding tumour (Carmeliet 2003). One of the most important angiogenic factors is vascular endothelial growth factor A (VEGFA), which stimulates vessel growth predominantly through VEGF receptor type 2 (VEGFR2; Ferrara 2004, Carmeliet 2005).

We and others have previously shown that curcumin has anti-proliferative and pro-apoptotic effects in cultured pituitary tumour cells and could inhibit the growth of experimentally induced GH3 cell pituitary tumours in athymic nude mice (Miller et al. 2008, Schaaf et al. 2009, Bangaru et al. 2010). In addition, we have demonstrated that curcumin could suppress VEGFA mRNA synthesis and secretion in a special non-hormone-producing pituitary cell type, the so-called folliculostellate (FS) cells (Schaaf et al. 2010). In the present paper, we have studied whether curcumin is a suppressor of both VEGFA secretion and HIF1A production in rodent and human pituitary tumour cells under normoxic and hypoxic conditions.

\section{Materials and Methods}

\section{Materials}

Cell culture materials and reagents were obtained from Life Technologies, Falcon (Heidelberg, Germany), Nunc (Wiesbaden, Germany), Seromed (Berlin, Germany), Flow Cytometry Standards Corp. (Meckenheim, Germany) and Sigma.

\section{Rodent and human pituitary tumour cells}

Corticotroph AtT20 mouse and lactosomatotroph GH3 rat pituitary tumour cell lines were cultured as reported (Shan et al. 2012) in DMEM (pH 7.3) supplemented with $10 \%(\mathrm{v} / \mathrm{v})$ FCS, $2 \times 10^{-3} \mathrm{~mol} / 1$ glutamine, $0.5 \mathrm{mg} / 1$ partricin and $10^{5} \mathrm{IU} / 1$ penicillin-streptomycin.

Primary human pituitary tumour cell cultures were prepared from the tissue of 22 non-functioning, four somatotrophs, four corticotrophs and two lactotroph adenomas (Table 1) that we received from different neurosurgical centres within $24 \mathrm{~h}$ after transsphenoidal surgery. The experiments with human material were performed after approval of the Local Ethics Committee (Ethics grant no. 141-07) and informed written consent was received from each patient whose pituitary adenoma tissue was used in the study. To obtain primary human pituitary tumour cell cultures, the adenoma tissue was enzymatically and mechanically dispersed as previously described (Renner et al. 1998) and the tumour cells obtained were carefully washed by repeated centrifugation. The cells were seeded onto wells of 48-well plates at a density of 100000 cells/well and were cultured in the above-described cell culture medium. Human pituitary adenoma cells were attached within $48 \mathrm{~h}$ and were then used for stimulation experiments. Owing to the limited amount of human adenoma tissue, enough cells were not obtained for primary cell cultures from each adenoma to perform all experiments in parallel.

\section{Treatment of cells}

For in vitro experiments HPLC-purified plant extract of curcumin (90\%; Sigma) was used. A stock solution of $10 \mathrm{mM}$ curcumin (prepared in DMSO) was diluted with cell culture medium to obtain final doses of $0 \cdot 5-30 \mu \mathrm{M}$ curcumin for cell treatments for various time periods as indicated. Controls with $0 \cdot 3 \%(\mathrm{v} / \mathrm{v})$ DMSO corresponding to the amount present in the highest curcumin dosage of $30 \mu \mathrm{M}$ were prepared in each experiment to exclude unspecific, toxic effects. DMSO alone had no effect on cell viability determined by ethidium bromide/acridine orange staining.

To study the effect of hypoxia on VEGFA and HIF1A production, cells were treated with cobalt chloride $\left(\mathrm{CoCl}_{2}\right)$, a well-established substance used to mimic hypoxic conditions (Ebert \& Bunn 1999, Masson \& Ratcliffe 2003, Yuan et al. 2003, Webb et al. 2009). In a previous study, we have shown that $\mathrm{CoCl}_{2}$ treatment and hypoxia $\left(1 \% \mathrm{O}_{2}\right)$ had similar effects on HIF1A and VEGFA production in pituitary tumour cells (Shan et al. 2012). $\mathrm{CoCl}_{2}$ was diluted in cell culture medium and was used at dosages between $31 \cdot 25$ and $250 \mu \mathrm{M}$. In experiments in which the effect of curcumin on $\mathrm{CoCl}_{2}$ was studied, curcumin was added to the tumour cell cultures $30 \mathrm{~min}$ before $\mathrm{CoCl}_{2}$ application. The viability of the $\mathrm{CoCl}_{2-}$ treated pituitary tumour cells was routinely controlled at the end of the experiments with the ethidium bromide/acridine orange method to exclude unspecific toxic effects of $\mathrm{CoCl}_{2}$. 
Table 1 Overview of the pituitary adenomas studied and the influence of curcumin on basal and $\mathrm{CoCl}_{2}$-induced VEGFA secretion in primary pituitary tumour cell cultures

\begin{tabular}{|c|c|c|c|c|c|}
\hline \multirow[b]{2}{*}{ Tumour } & \multirow[b]{2}{*}{ Sex/age } & \multicolumn{4}{|c|}{ VEGFA secretion } \\
\hline & & Basal VEGFA ${ }^{\mathrm{a}}$ & $\begin{array}{l}\text { Inhibition by } \\
\text { curcumin }^{b}(\%)\end{array}$ & $\begin{array}{l}\mathrm{CoCl}_{2} \text {-induced } \\
\text { VEGFA }^{\mathrm{C}}\end{array}$ & 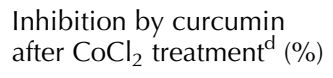 \\
\hline ST2 & $\mathrm{F} / 63$ & $41 \cdot 5 \pm 7 \cdot 2$ & $56 \cdot 1^{\neq}$ & ND & ND \\
\hline ST3 & $\mathrm{F} / 40$ & $139 \cdot 8 \pm 17 \cdot 3$ & $45 \cdot 3^{\neq}$ & $1158 \cdot 9 \pm 115 \cdot 3$ & $57 \cdot 1^{\S}$ \\
\hline ST4 & $M / 37$ & $122 \cdot 6 \pm 28 \cdot 1$ & $39 \cdot 9^{\ddagger}$ & $989 \cdot 2 \pm 118 \cdot 9$ & $77 \cdot 7^{\S}$ \\
\hline NT3 & $M / 58$ & $449 \cdot 8 \pm 35 \cdot 5$ & $50 \cdot 6^{\neq}$ & ND & ND \\
\hline NT4 & $\mathrm{F} / 77$ & $327 \cdot 0 \pm 39 \cdot 6$ & $50 \cdot 1^{\neq}$ & ND & ND \\
\hline NT5 & $\mathrm{F} / 40$ & $35 \cdot 4 \pm 2 \cdot 5$ & $61 \cdot 5^{\neq}$ & $220 \cdot 5 \pm 18 \cdot 1$ & $70 \cdot 1^{\S}$ \\
\hline NT6 & $F / 24$ & $67 \cdot 6 \pm 8 \cdot 6$ & $73 \cdot 1^{\neq}$ & $231 \cdot 3 \pm 21 \cdot 4$ & $55 \cdot 7^{\S}$ \\
\hline NT7 & $M / 42$ & $483 \cdot 1 \pm 40 \cdot 9$ & $79 \cdot 1^{\neq}$ & ND & ND \\
\hline NT8 & M/52 & $86 \cdot 9 \pm 12 \cdot 3$ & $58 \cdot 3^{+}$ & $294 \cdot 6 \pm 46 \cdot 7$ & $70 \cdot 4^{\S}$ \\
\hline NT14 & $\mathrm{F} / 71$ & $92 \cdot 1 \pm 9 \cdot 8$ & $56 \cdot 6^{\neq}$ & $402 \cdot 4 \pm 35 \cdot 3$ & $73 \cdot 6^{\S}$ \\
\hline NT15 & $M / 38$ & $225 \cdot 4 \pm 13 \cdot 7$ & $34 \cdot 9^{\ddagger}$ & ND & ND \\
\hline NT16 & $M / 68$ & $16 \cdot 7 \pm 1 \cdot 8$ & $65 \cdot 7^{\ddagger}$ & $93 \cdot 6 \pm 9 \cdot 9$ & $66 \cdot 6^{\S}$ \\
\hline NT17 & $M / 45$ & $31 \cdot 1 \pm 4 \cdot 9$ & $56 \cdot 9^{\ddagger}$ & $128 \cdot 8 \pm 5 \cdot 3$ & $73 \cdot 5^{\S}$ \\
\hline NT18 & $F / 68$ & $62 \cdot 2 \pm 6 \cdot 3$ & $75 \cdot 0^{\ddagger}$ & $379 \cdot 1 \pm 41 \cdot 9$ & $67 \cdot 8^{\S}$ \\
\hline NT19 & $M / 62$ & $82 \cdot 8 \pm 9 \cdot 3$ & $67 \cdot 4^{\ddagger}$ & $213 \cdot 3 \pm 14 \cdot 6$ & $37 \cdot 2^{\S}$ \\
\hline NT20 & $M / 51$ & $311 \cdot 6 \pm 24 \cdot 6$ & $65 \cdot 5^{\ddagger}$ & $630 \cdot 4 \pm 68 \cdot 1$ & $59 \cdot 9^{\S}$ \\
\hline NT21 & $M / 65$ & $71 \cdot 6 \pm 5 \cdot 1$ & $45 \cdot 5^{\dagger}$ & $193 \cdot 1 \pm 18 \cdot 2$ & $54 \cdot 8^{\S}$ \\
\hline NT22 & $\mathrm{M} / 42$ & $124 \cdot 2 \pm 8 \cdot 1$ & $61 \cdot 0^{\ddagger}$ & $414 \cdot 6 \pm 33 \cdot 1$ & $64 \cdot 1^{\S}$ \\
\hline CT1 & $M / 57$ & $22 \cdot 5 \pm 1 \cdot 3$ & $26 \cdot 9 *$ & ND & ND \\
\hline CT2 & $M / 56$ & $95 \cdot 8 \pm 11 \cdot 2$ & $56 \cdot 2^{\ddagger}$ & ND & ND \\
\hline СТ3 & $\mathrm{F} / 33$ & $76 \cdot 9 \pm 8 \cdot 6$ & $54 \cdot 5^{\ddagger}$ & ND & ND \\
\hline СТ4 & M/37 & $28 \cdot 3 \pm 2 \cdot 9$ & $39 \cdot 6^{\ddagger}$ & $317 \cdot 2 \pm 9 \cdot 7$ & $55 \cdot 1^{\S}$ \\
\hline
\end{tabular}

VEGFA, vascular endothelial growth factor A; ST, somatotroph tumour; NT, non-functioning tumour; $C T$, corticotroph tumour, LT, lactotroph tumour; $\mathrm{F}$, female; $\mathrm{M}$, male; ND, not done. ${ }^{*} P<0 \cdot 05,{ }^{\dagger} P<0 \cdot 01,{ }^{\ddagger} P<0 \cdot 001$ vs basal VEGFA; ${ }^{\circledR} P<0 \cdot 001$ vs $\mathrm{CoCl}_{2}$-induced VEGFA.

${ }^{a}$ Picogram VEGFA per millilitre after $24 \mathrm{~h}$ incubation.

${ }^{b}$ Percent reduction of basal $(=100 \%)$ VEGFA.

CPicogram VEGFA per millilitre after treatment with $125 \mu \mathrm{M} \mathrm{CoCl}_{2}$ for $24 \mathrm{~h}$.

${ }^{\mathrm{d}}$ Percent reduction of $\mathrm{CoCl}_{2}$-induced VEGFA ( $=100 \%$ ).

Even after the longest treatment periods $(72 \mathrm{~h})$ with the highest $\mathrm{CoCl}_{2}$ dose $(250 \mu \mathrm{M})$, we observed no changes in the viability of the tumour cells.

\section{Real-time RT-PCR}

To study the influence of curcumin on the mRNA synthesis of VEGFA and HIF1A in pituitary tumour cells, real-time RT-PCR was performed as previously described (Shan et al. 2012). In brief, RNA was extracted from GH3 and AtT-20 cells using TRIzol reagent (Invitrogen) according to the manufacturer's instruction. One microgram total RNA was reverse transcribed using random hexanucleotides under restrictive conditions (Pagotto et al. 2000). Quantitative real-time RT-PCR was performed with cDNA samples of
GH3 and AtT-20 cells as templates. The amplification reactions of 35 cycles were carried out with specific primers for mouse HIF1A (sense: $5^{\prime}$-TAC TGA GTT GAT GGG TTA TGA-3', antisense: $5^{\prime}$-AAG GCA GCT TGT ATC CTC- $3^{\prime}$ ), mouse VEGFA (sense: $5^{\prime}$-TCT ACC AGC GAA GCT ACT GCC- $3^{\prime}$, antisense: $5^{\prime}$-TTA CAC GTC TGC GGA TCT TG-3'), rat HIF1A (sense: $5^{\prime}$-GCA GCG ATG ACA CGG AAA C- $3^{\prime}$, antisense: $5^{\prime}$-CAT ATC GCT GTC CAC ATC AAA- ${ }^{\prime}$ ) and rat VEGF (sense: $5^{\prime}$-GAC GTC TAC CAG CGC AGC TAT- $3^{\prime}$, antisense: $5^{\prime}$-AAA TGC TTT CTC CGC TCT GAA-3'). Mouse $\beta$-actin (sense: 5'-AGT ATC CAT GAA ATA AGT GGT TAC AGG-3', antisense: $5^{\prime}$-CAC TTT TAT TGG TCT CAA GTC AGT GTA-3') and rat HPRT (sense: $5^{\prime}$-ACT GAA AGA CTT GCT CGA GAT-3', antisense: 5'-CCG TTG ACT GGT 
CAT TAC AG-3') were used as references. Absolute Blue QPCR SYBR Green Mix (Thermo Scientific, Braunschweig, Germany) was used following the manufacturer's instructions. PCR amplifications were performed in a MiniOpticon Real-Time PCR Detection System (Bio-Rad), and the data were analysed using CFX Manager Software for MiniOpticon (version 1.5, Bio-Rad). For each sample, the values were normalised by the amount of $\beta$-actin. All experiments were carried out in triplicates.

\section{Measurement of VEGFA}

For the determination of VEGFA secretion, 50000 AtT20 or GH3 cells or 100000 human pituitary adenoma cells were seeded into 48 -well plates containing $0.5 \mathrm{ml}$ culture medium. After attachment, the cells were stimulated as indicated and VEGFA was measured in the cell culture supernatant using mouse-, rat- or human-specific VEGFA ELISA kits (R\&D Systems, Wiesbaden, Germany) following the manufacturer's instruction. All secretion experiments were carried out in quadruplicates.

\section{HIF1A analysis by western-immunoblotting}

To study HIF1A protein production, AtT20 and GH3 cells were seeded into a six-well plate, grown to about $80 \%$ confluence and then treated with curcumin $/ \mathrm{CoCl}_{2}$ as indicated. Cells from each well were separately harvested by scraping and applied to protein extraction. Human adenoma cells were cultured in 48-well plates (100 000 cells/well) and cells from eight wells were treated under the same conditions and pooled for protein extraction. Cell lysates were harvested in RIPA lysis buffer supplemented with protease inhibitor cocktail (Sigma). The protein concentrations of the cell lysates were determined by Bradford dye assay (Bradford 1976). Thirty micrograms of each sample were separated by a precast Tris-glycine gel (Anamed, Darmstadt, Germany) in an electrophoresis apparatus (Invitrogen) and then transferred on a nitrocellulose membrane (Hybond ECL) with Novex Semi-Dry Blotter (Invitrogen). The membranes were then blocked in $5 \%(\mathrm{w} / \mathrm{v})$ non-fat milk solution (dissolved in TBS $/ 0 \cdot 1 \%$ Tween) and incubated overnight at $4{ }^{\circ} \mathrm{C}$ with mouse monoclonal antibody against HIF1A (R\&D Systems) diluted $1: 500$ in $2 \cdot 5 \%(\mathrm{w} / \mathrm{v})$ non-fat milk solution. After washing three times with TBS/0 $1 \%(\mathrm{v} / \mathrm{v})$ Tween, the membranes were incubated with HRP-conjugated anti-mouse antibody (Cell Signaling, Frankfurt, Germany) diluted $1: 2000$ in $2 \cdot 5 \%(\mathrm{w} / \mathrm{v})$ non-fat milk solution. The ECL system and hyperfilm (GE Healthcare, Munich, Germany) were used for membrane visualisation.

\section{Statistical analysis}

Each of the experiments with rodent pituitary tumour cell lines was repeated at least three times. The individual experiments with cell lines and primary human pituitary adenoma cell cultures were performed using quadruplicate wells. Results are expressed as mean \pm s.D. One-way ANOVA was used to compare variables, and $P<0.05$ was considered as significant. The statistical analyses were performed with SigmaStat 2.0 (SPSS, Inc., Ehningen, Germany).

\section{Results}

Effect of curcumin on basal VEGFA production in pituitary tumour cells

Quantitative RT-PCR showed that $24 \mathrm{~h}$ of curcumin application led to a dose-dependent reduction of the basal VEGFA mRNA synthesis in both GH3 cells and AtT20 cells (Fig. 1A and B). Consequently, the VEGFA secretion in both pituitary tumour cell lines was dose dependently suppressed by curcumin not only after $24 \mathrm{~h}$ but also after longer exposure times (Fig. 1C and D).

In primary cell culture, all 32 human adenomas studied secreted VEGFA under basal conditions. The release of VEGFA per 100000 adenoma cells per well was highly variable resulting in different concentrations of VEGFA in the cell culture supernatants ranging from $16 \cdot 7 \pm 1 \cdot 8$ to $483 \cdot 1 \pm 40 \cdot 9 \mathrm{pg} / \mathrm{ml}$ VEGFA after $24 \mathrm{~h}$ (Table 1). Treatment of primary adenoma cell cultures with different doses of curcumin $(1-30 \mu \mathrm{M})$ led to a dose-dependent suppression of basal VEGFA production (Fig. 2 shows representative results for different human pituitary adenomas under different treatment regimens). Significant suppression was achieved with 20 and $30 \mu \mathrm{M}$ curcumin in all adenomas (in Table 1 the reduction of basal VEGFA in percent is summarised for the $24 \mathrm{~h}$ treatment with $30 \mu \mathrm{M}$ curcumin) and with $10 \mu \mathrm{M}$ in most (83\%) tumour cell cultures. However, in some cases even 5 and $1 \mu \mathrm{M}$ curcumin significantly inhibited basal VEGFA production (Fig. 2). Time course studies of up to $72 \mathrm{~h}$ showed that the increase in VEGFA secretion was consistently suppressed by curcumin. The suppressive effect of curcumin was not dependent on the type of adenoma or the basal secretion rate of VEGFA.

DMSO, which is widely used as solvent for lipophilic drugs, has multiple in vitro and in vivo actions on its own (Santos et al. 2003), including stimulatory and inhibitory effects on growth hormone $(\mathrm{GH})$ and prolactin (PRL) production (Nagasawa 1983, Abdel-Haq et al. 2000). However, careful searches of the literature gave no hints that DMSO itself had effects on VEGFA or HIF1A production. Nevertheless, the effects of the maximum vehicle dose $(0 \cdot 3 \%$ DMSO) on HIF1A and VEGFA production were controlled in all experiments with the exception of a few human adenomas in which very limited tissue material was available. DMSO $(0 \cdot 3 \%)$ had no significant effect on basal mRNA synthesis and secretion of VEGFA in AtT20 and GH3 cells (Fig. 1) and in those human adenoma cultures in which the effect of DMSO was tested (not shown). 
A
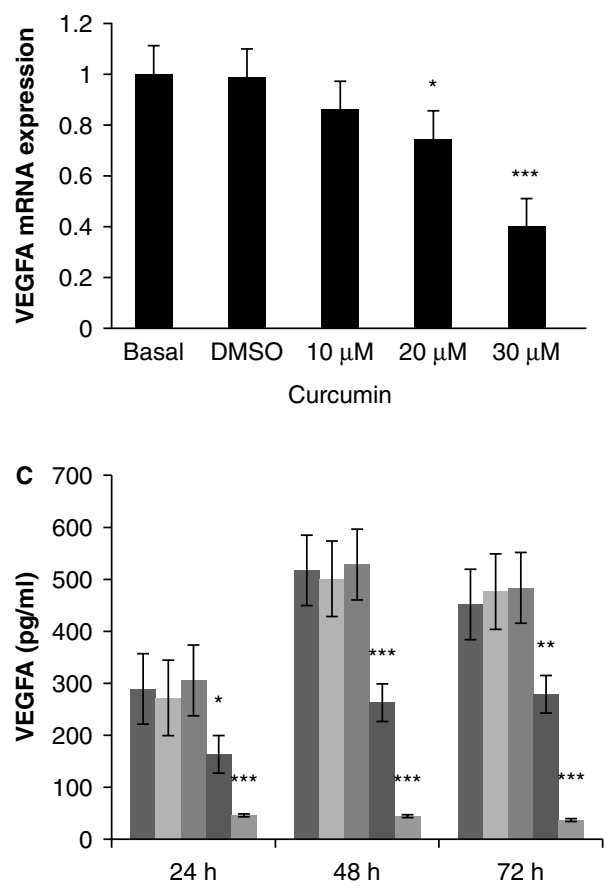

B
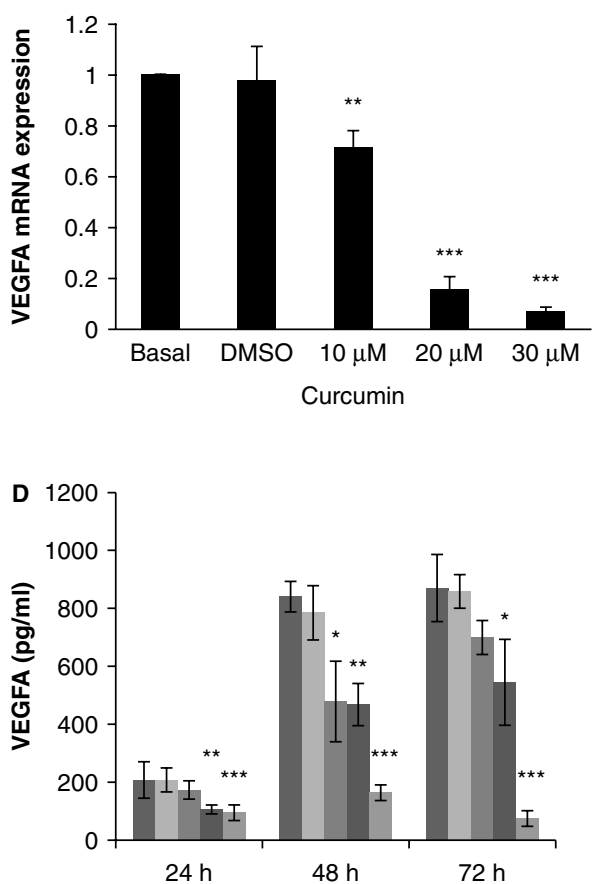

Figure 1 Effect of curcumin on the basal mRNA synthesis and release of VEGFA in endocrine pituitary tumour cell lines. $24 \mathrm{~h}$ treatment with curcumin dose-dependently inhibited mRNA synthesis in corticotroph AtT20 (A) and lactosomatotroph GH3 (B) cells, whereas DMSO (0.3\% in culture medium) had no effect. Data are expressed as relative mRNA expression in comparison with basal $(=1)$.

The secretion of VEGFA by AtT20 (C) and GH3 (D) cells was also dose-dependently suppressed by curcumin but not by DMSO after different treatment periods. For each time point grouped bars correspond - from left to right - to basal, DMSO, and 10,20 and $30 \mu \mathrm{M}$ curcumin treatment conditions. ${ }^{*} P<0 \cdot 05$; ${ }^{* *} P<0 \cdot 01 ;{ }^{* * * P}<0 \cdot 001$ vs corresponding basal conditions.

\section{Influence of curcumin on HIF1A production in pituitary tumour cells}

We have recently demonstrated that the treatment of pituitary tumour cells with the hypoxia-mimicking agent $\mathrm{CoCl}_{2}$ had a similar effect on HIF1A production as observed under hypoxic $\left(1 \% \mathrm{O}_{2}\right)$ conditions (Shan et al. 2012). Therefore, in this paper only the effect of curcumin on $\mathrm{CoCl}_{2}$-induced $H I F 1 A$ mRNA synthesis and protein production was studied in AtT20 and GH3 cells and in eight human pituitary adenomas, from which sufficient cells were available. In all experiments, curcumin was added to the cell cultures $30 \mathrm{~min}$ before $\mathrm{CoCl}_{2}$ treatment. Twenty-four hours treatment with curcumin dose dependently suppressed not only $\mathrm{CoCl}_{2-}$ induced but also basal HIF1A mRNA synthesis in both GH3 (Fig. 3A) and AtT20 cells (not shown). In a previous paper, we have shown that HIF1A protein levels reach maximum levels in pituitary tumour cells after $3 \mathrm{~h}$ treatment with $\mathrm{CoCl}_{2}$ (Shan et al. 2012). Pretreatment of pituitary tumour cell lines with different dosages of curcumin for $30 \mathrm{~min}$ and subsequent application of $\mathrm{CoCl}_{2}$ for $3 \mathrm{~h}$ led to a significant and dosedependent reduction in HIF1A protein formation both in AtT20 and GH3 cells (Fig. 3). The same was observed in eight human adenoma cell cultures, in which curcumin also suppressed the $\mathrm{CoCl}_{2}$-induced HIF1A protein production (representative results are shown in Fig. 3). DMSO (0.3\%) had no effect on HIF1A production in the cell lines and adenoma cell cultures (not shown).

\section{Influence of curcumin on the VEGFA secretion of pituitary tumour cells under hypoxia-mimicking conditions}

As we have previously shown that the VEGFA production by AtT20 cells could not be stimulated under hypoxiamimicking conditions for reasons that are still not known (Shan et al. 2012), the effect of curcumin on $\mathrm{CoCl}_{2}$-induced mRNA synthesis and secretion of VEGFA were studied only in the GH3 pituitary tumour cell line. Increasing doses $(62 \cdot 5,125$ and $250 \mu \mathrm{M})$ of $\mathrm{CoCl}_{2}$ significantly increased VEGFA secretion, which was dose-dependently suppressed by curcumin (Fig. 4B). The latter also inhibited the $\mathrm{CoCl}_{2}-$ induced VEGFA mRNA synthesis, whereby $10 \mu \mathrm{M}$ curcumin already completely abolished the $\mathrm{CoCl}_{2}$-stimulated VEGFA mRNA production (Fig. 4A).

In 16 human adenoma cell cultures, the effect of hypoxiamimicking $\mathrm{CoCl}_{2}$ treatment was studied and in all tumour cell cultures a strong increase in VEGFA production was 

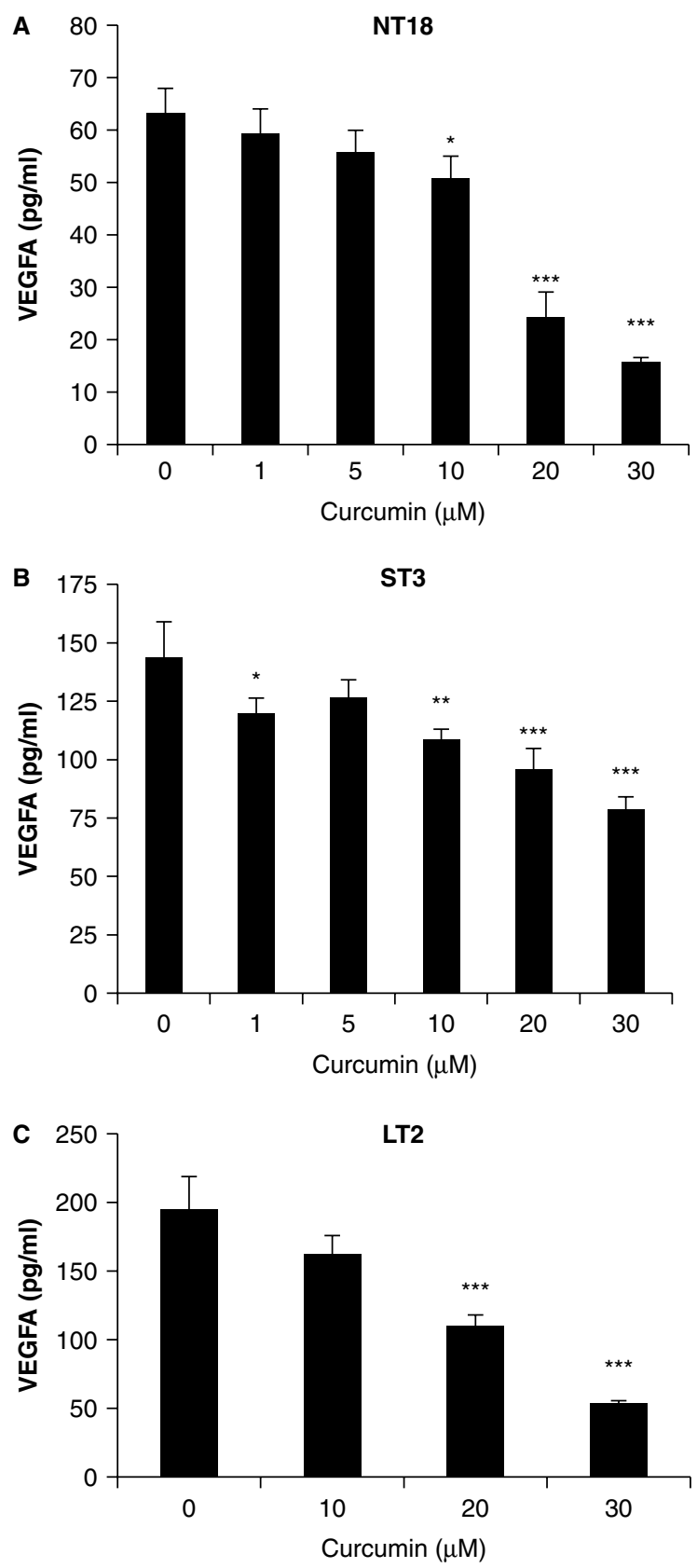

Figure 2 Effect of curcumin on the basal VEGFA release in three representative human pituitary adenoma cell cultures. Curcumin dose-dependently suppressed the VEGFA secretion in primary cell cultures of a non-functioning (A), a somatotroph (B) and a lactotroph $(C)$ pituitary tumour. The cell cultures were treated with curcumin for $24 \mathrm{~h}$ in $\mathrm{A}$ and $\mathrm{B}$ and for $72 \mathrm{~h}$ in $\mathrm{C}$. ${ }^{*} P<0 \cdot 05$; ${ }^{* *} P<0 \cdot 01 ;{ }^{* * *} P<0.001$ vs corresponding untreated cell cultures.

observed (Table 1). In some adenomas, in which the effect of different $\mathrm{CoCl}_{2}$ doses on VEGFA secretion was studied, maximum effects were found with $125 \mu \mathrm{M} \mathrm{CoCl}_{2}$ (data not shown) and therefore this dosage was used in all further adenoma investigated. As summarised in Table 1, VEGFA secretion was stimulated two- to tenfold under hypoxiamimicking conditions. In general, a stronger induction was observed in those tumours with low basal VEGFA secretion rates. Curcumin dose-dependently suppressed the $\mathrm{CoCl}_{2}-$ induced VEGFA secretion not only after $24 \mathrm{~h}$ (Table 1; Fig. 5A, B, C and D) but also after prolonged treatment periods (48 and 72 h; Fig. 5A), and in several cases significant suppression was already achieved at $5 \mu \mathrm{M}$ curcumin (Fig. 5B and $\mathrm{C})$. In some cases, the highest doses of curcumin $(30 \mu \mathrm{M})$ even completely abolished $\mathrm{CoCl}_{2}$-induced VEGFA production (Fig. 5C). In summary, curcumin strongly suppressed not only basal but also $\mathrm{CoCl}_{2}$-induced VEGFA secretion in all human endocrine-active and -inactive pituitary adenoma cell cultures studied.

\section{Discussion}

Anti-angiogenic treatment concepts targeting the VEGFA/ VEGFA receptor system are one of the most promising approaches for the treatment of different types of solid tumours (Wahl et al. 2011). It is thought that the resulting disturbance of tumour neovascularisation stops further tumour expansion and may probably induce tumour shrinkage. Curcumin, a polyphenolic compound of the spice plant $C$. longa, was shown to have anti-angiogenic properties in several types of tumours (Kunnumakkara et al. 2008, Yadav \& Aggarwal 2011). Here, we could demonstrate that curcumin strongly suppresses the release of proangiogenic VEGFA under basal and hypoxia-mimicking conditions in rodent and human pituitary tumour cells and moreover inhibits HIF1A protein production.

HIF1A protein expression has been immunohistochemically demonstrated to be present in pituitary adenomas but not in normal anterior pituitaries (Vidal et al. 2003, Kim et al. 2005). Thus, as in any kind of solid tumour, it seems that pituitary adenoma neovascularisation is controlled by this transcription factor representing the major regulator of genes whose products are involved in angiogenic processes (Harris 2002, Hickey \& Simon 2006). In cultured pituitary tumour cell lines or in primary cell cultures of human pituitary adenomas, we found HIF1A mRNA but not HIF1A protein under basal conditions because the latter on one hand is continuously synthesised but on the other hand is rapidly degraded by ubiquitination under normoxic conditions as they are present in cell culture (Wei \& Yu 2007). Under hypoxic (incubation at $1 \% \quad \mathrm{O}_{2}$ ) or hypoxia-mimicking $\left(\mathrm{CoCl}_{2}\right.$-treatment) conditions the degradation of HIF1A protein is suppressed and thus strongly increases in the pituitary tumour cells, reaching maximum values after $2-3 \mathrm{~h}$, as we have reported previously (Shan et al. 2012). Curcumin potently inhibited HIF1A protein production both in rodent endocrine pituitary tumour cell lines and in cells of different human pituitary adenoma types. This has also been observed for curcumin and its derivatives in a variety of cell lines 


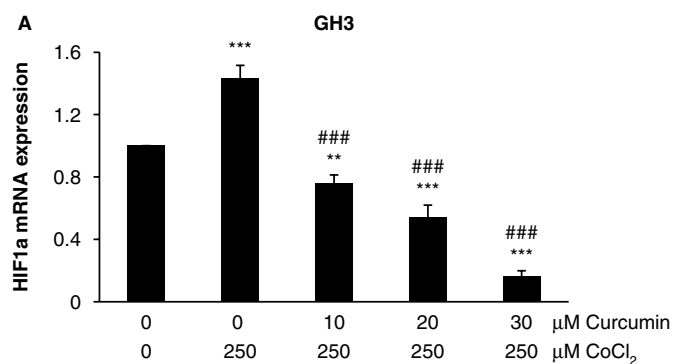

B

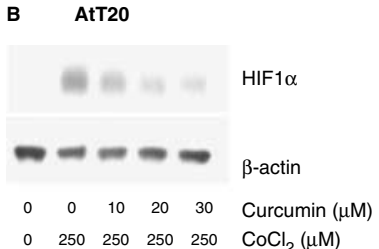

C $\quad$ GH3

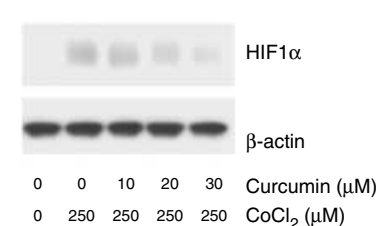

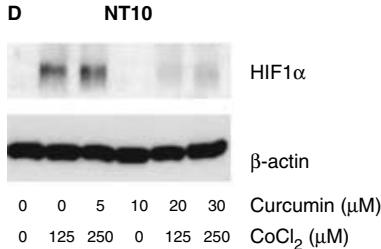

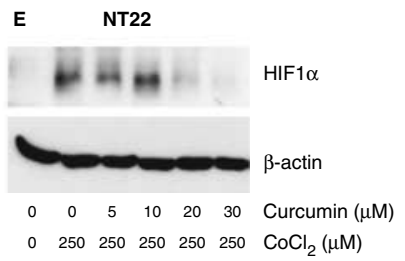

Figure 3 Effect of curcumin on HIF1A mRNA synthesis and protein production in pituitary tumour cells. (A) $24 \mathrm{~h}$ treatment with $\mathrm{CoCl}_{2}$ (hypoxia-mimicking conditions) enhanced HIF1A mRNA synthesis. Increasing curcumin dosages not only reverted the $\mathrm{CoCl}_{2}$-induced increase but also reduced basal HIF1A mRNA levels. Data are shown as relative mRNA expression in comparison to basal $(=1)$. $(\mathrm{B}, \mathrm{C}, \mathrm{D}$ and $\mathrm{E})$ Western blots showing the induction of HIF1A protein in response to $\mathrm{CoCl}_{2}$ treatment and its suppression by curcumin in pituitary tumour cell lines (B and $\mathrm{C}$ ) and representatively in cell cultures of two non-functioning human pituitary adenomas ( $\mathrm{D}$ and $\mathrm{E})$. For studies on HIF1A protein production, treatment periods with $\mathrm{CoCl}_{2}$ were $3 \mathrm{~h}$ in each experiment. ${ }^{* *} P<0 \cdot 01 ;{ }^{* * *} P<0 \cdot 001$ vs basal HIF1A mRNA; ${ }^{\# \#} P<0 \cdot 001$ vs $\mathrm{CoCl}_{2}$-induced HIF1A mRNA.

serving as models of different types of tumours (Bae et al. 2006, Thomas et al. 2008, Jung et al. 2010, Ströfer et al. 2011). To the best of our knowledge, this is the first study demonstrating that curcumin also suppresses HIF1A protein production in primary culture of human tumour cells. In addition to protein suppression, curcumin could also completely inhibit hypoxia-induced $H I F 1 A$ mRNA synthesis and even suppressed basal HIF1A mRNA production. Thus, curcumin not only interferes with the HIF1A protein generation and/or stabilisation system but also downregulates HIF1A at the mRNA level, suggesting that different mechanisms of action mediate the overall inhibitory role of curcumin on HIF1A production. In a series of carcinoma cell lines, it has been shown that curcumin was not able to affect HIF1A production but suppressed HIF1 by down-regulating HIF1B (aryl hydrocarbon receptor nuclear translocator (ARNT)), the hypoxia-independent subunit of HIF1
(Choi et al. 2006). In other cell types, curcumin concomitantly suppressed HIF1A and HIF1B (Ströfer et al. 2011). Whether the latter mode of curcumin-induced HIF1 suppression plays a role in pituitary tumour cells remains to be clarified in future studies.

The transcription factor HIF1 induces its angiogenic effects by stimulating different angiogenic factors, among which VEGFA is the most important. However, VEGFA also has other physiological functions such as maintaining the existing blood vessel system and regulating the vessel permeability by stimulating capillary fenestration (Ferrara 2004). An extremely dense intrapituitary vascular system (Viacava et al. 2003) and highly permeable capillary endothelial cells are essential for the rapid regulation and release of hormones within the anterior pituitary (Lafont et al. 2010). Therefore, VEGFA is already produced under normoxic conditions in the normal pituitary by FS cells, which are considered to be the major source of this factor in the adenohypophysis (Gospodarowicz et al. 1989, Gloddek et al. 1999). As curcumin was found to suppress VEGFA secretion by FS cells in the normal pituitary (Schaaf et al. 2010), it may attenuate the above-mentioned physiological functions of VEGFA, which needs to be clarified in future studies.
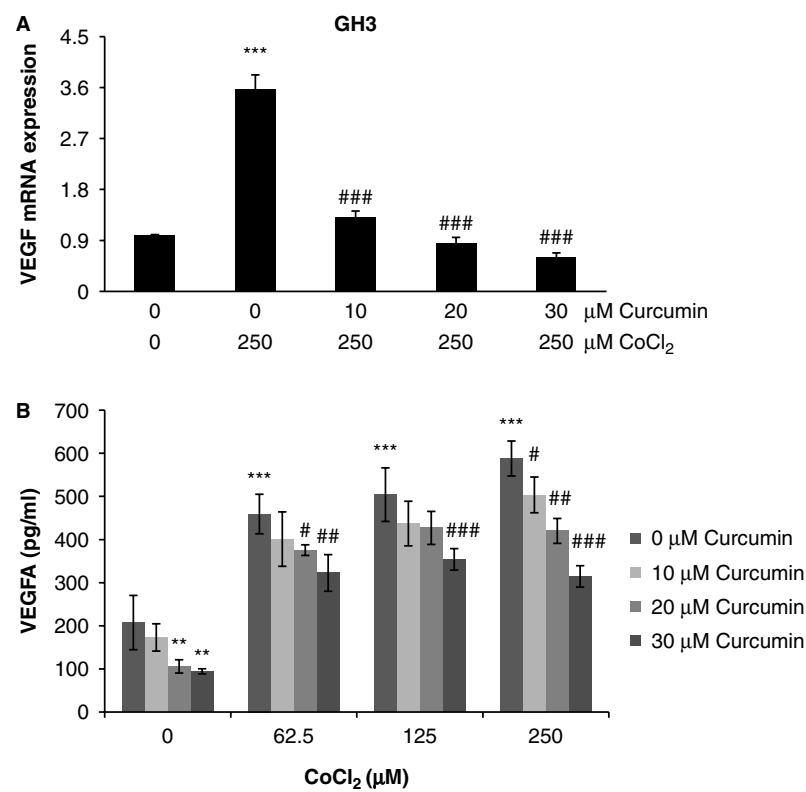

Figure 4 Influence of curcumin on $\mathrm{CoCl}_{2}$-induced mRNA synthesis and secretion of VEGFA in $\mathrm{GH} 3$ cells. (A) Hypoxia-mimicking conditions $\left(24 \mathrm{~h}\right.$ treatment with $\mathrm{CoCl}_{2}$ ) induced a strong increase in VEGFA mRNA synthesis in lactosomatotroph $\mathrm{GH} 3$ pituitary tumour cells that was completely abolished after application of increasing amounts of curcumin. (B) VEGFA secretion induced by different doses of $\mathrm{CoCl}_{2}$ was also dose-dependently suppressed by curcumin, although the inhibition was less strong as for mRNA synthesis. ${ }^{* *} P<0 \cdot 01 ; * * * P<0 \cdot 001$ vs basal VEGFA mRNA synthesis or secretion respectively. ${ }^{\#} P<0 \cdot 05 ;{ }^{\#} P<0 \cdot 01 ;{ }^{\# \#} P<0 \cdot 001$ vs $\mathrm{CoCl}_{2}$-induced VEGFA mRNA synthesis or secretion respectively. 


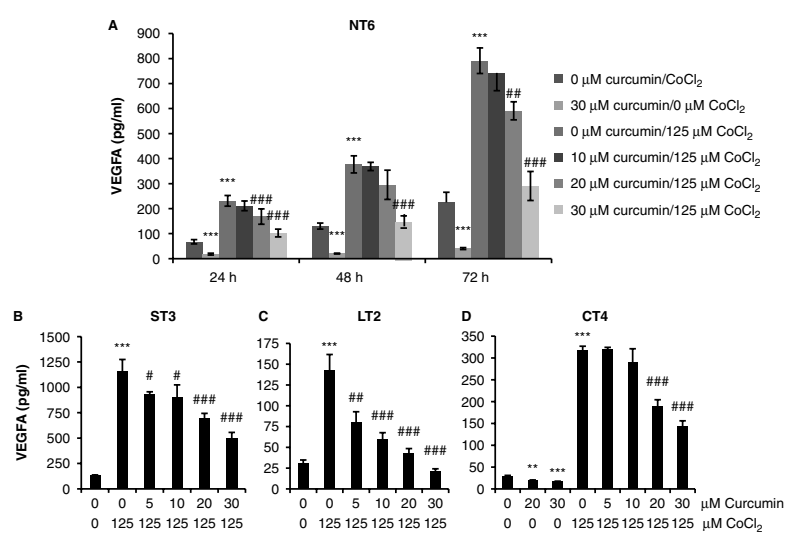

Figure 5 Influence of curcumin on $\mathrm{CoCl}_{2}$-induced VEGFA secretion in human pituitary adenoma cell cultures. (A) The time-dependent increase in basal and $\mathrm{CoCl}_{2}$-induced VEGFA secretion was dosedependently suppressed by curcumin for each time period studied. $(\mathrm{B}, \mathrm{C}$ and $\mathrm{D})$ Dose-dependent inhibition of $\mathrm{CoCl}_{2}$-stimulated VEGFA release by curcumin ( $24 \mathrm{~h}$ treatment period) in somatotroph (B), lactotroph (C) and corticotroph (D) adenoma cell cultures. ${ }^{* *} P<0.01 ;{ }^{* * *} P<0.001$ vs corresponding basal VEGFA secretion. ${ }^{\#} P<0 \cdot 05 ;{ }^{\#} P<0 \cdot 01 ;{ }^{\# \#} P<0.001$ vs corresponding $\mathrm{CoCl}_{2}$-induced VEGFA release.

In pituitary adenomas, FS cells are absent or rare and only very few cases of endocrine-inactive FS cell adenomas have been reported so far (Iwaki et al. 1986, Farnoud et al. 1994, Hori et al. 2009). Therefore, in most endocrine-active or -inactive pituitary adenomas, the tumour cells themselves are capable of producing VEGFA (Lloyd et al. 1999, Lohrer et al. 2001, Viacava et al. 2003). As shown here and in previous papers (Lohrer et al. 2001, Shan et al. 2012), cultured pituitary adenoma cells secrete VEGFA already under normoxic conditions in the absence of HIF1A. Thus, VEGFA production is in part an autonomous process or it is regulated by other factors (e.g. growth factors, cytokines and neuropeptides), many of which are produced within the tumour and may thus hypoxia-independently stimulate VEGFA by auto/paracrine mechanisms (Lohrer et al. 2001, Renner et al. 2004). This may explain why no correlation between the expression of VEGFA and HIF1A in pituitary adenomas was found in an immunohistochemical study (Kim et al. 2005).

Little is known in detail about the processes regulating pituitary tumour neovascularisation (Turner et al. 2000), but as in any solid tumour type, hypoxia may be the driving force (Harris 2002). We speculate that the basal VEGFA production is needed to maintain the already achieved intratumoural vasculature and to affect vessel permeability but may not be sufficient to induce angiogenesis. The latter may take place only transiently and locally in areas in which slowly growing pituitary adenoma cells have formed a not yet vascularised tumour cell population. If the oxygen supply of this cell population by diffusion declines, HIF1 production and VEGFA release will strongly increase to induce in concert with other HIF1-induced angiogenic factors the neovascularisation of this adenoma cell population. This idea is supported by our findings that the basal VEGFA secretion of human pituitary adenoma cells was further strongly enhanced under hypoxia-mimicking conditions with the most prominent induction in adenoma cell cultures with low basal VEGFA secretion rates.

We could demonstrate that curcumin inhibited both basal and $\mathrm{CoCl}_{2}$-induced VEGFA synthesis and secretion in pituitary tumour cells. In particular, the strong increase in VEGFA secretion under hypoxia-mimicking conditions in human adenoma cell cultures was in some cases completely reverted by curcumin, suggesting that this substance may have potent anti-angiogenic activities in pituitary adenomas. Most likely the suppressive effect of curcumin on HIF1A protein production was responsible for the reduction of VEGFA production and release. However, as the basal and HIF1A-independent release of VEGFA was also suppressed by curcumin, it is evident that other mechanisms involved in VEGFA production were also affected. It is known that curcumin has multiple targets and therefore interferes with multiple second messenger systems, intracellular signalling pathways and transcription factors (Kunnumakkara et al. 2008, Gupta et al. 2011), some of which are involved in the stimulatory action of different growth factors and neuropeptides on VEGFA secretion in pituitary adenomas (Renner et al. 2004). For instance, it has been shown that TGF-B-induced VEGFA production, a process that is also critically involved in pituitary tumour development (Renner et al. 2002), was significantly blocked by curcumin in human HT-1080 fibrosarcoma cells (Shih \& Claffey 2001). Whether this mode of action of VEGFA suppression by curcumin and other mechanisms play a role in pituitary adenomas needs to be clarified still.

As we have previously shown, VEGFA affects not only vascular function and growth in pituitary adenomas but also stimulates proliferation of pituitary tumour cells (Onofri et al. 2006). These effects are mediated through differently localised VEGFA receptors, whereby the VEGFR1 is predominantly expressed on tumour cells and the VEGFR2 is exclusively located in endothelial cells (Onofri et al. 2006). Thus, through the inhibition of VEGFA, curcumin would not only impair the vascularisation of pituitary adenomas but would also suppress the growth stimulatory effects of VEGFA on pituitary tumours.

In summary, curcumin not only demonstrates the recently described anti-proliferative and pro-apoptotic effects in pituitary tumours but also displays anti-angiogenic properties by reducing the intratumoural production of HIF1A and VEGFA, which play important roles in angiogenesis-driven tumour neovascularisation. Therefore, if the problems of the poor bioavailability of curcumin can be solved, stable curcumin derivatives may be attractive candidates for the development of a multi-targeting therapy of pituitary adenomas. 


\section{Declaration of interest}

The authors declare that there is no conflict of interest that could be perceived as prejudicing the impartiality of the research reported.

\section{Funding}

This research did not receive any specific grant from any funding agency in the public, commercial or not-for-profit sector.

\section{References}

Abdel-Haq H, Giacomelli S, Palmery M, Leone MG, Saso L \& Silvestrini B 2000 Aflatoxins inhibit prolactin secretion by rat pituitary cells in culture. Drug and Chemical Toxicology 23 381-386. (doi:10.1081/DCT-100100123)

Asa SL \& Ezzat S 2009 The pathogenesis of pituitary tumors. Annual Review of Pathology 4 97-126. (doi:10.1146/annurev.pathol.4.110807.092259)

Bae MK, Kim SH, Jeong JW, Lee YM, Kim HS, Kim SR, Yun I, Bae SK \& Kim KW 2006 Curcumin inhibits hypoxia-induced angiogenesis via downregulation of HIF-1. Oncology Reports 15 1557-1562.

Bangaru ML, Woodliff J, Raff H \& Kansra S 2010 Growth suppression of mouse pituitary corticotroph tumor AtT20 cells by curcumin: a model for treating Cushing's disease. PLoS ONE 5 e9893. (doi:10.1371/journal.pone. 0009893)

Bradford MM 1976 A rapid and sensitive method for the quantification of microgram quantities of protein utilizing the principle of protein-dye binding. Analytical Biochemistry 72 248-254. (doi:10.1016/00032697(76)90527-3)

Carbia-Nagashima A, Gerez J, Perez-Castro C, Paez-Pereda M, Silberstein S, Stalla GK, Holsboer F \& Arzt E 2007 RSUME, a small RWD-containing protein, enhances SUMO conjugation and stabilizes HIF- $1 \alpha$ during hypoxia. Cell 131 309-323. (doi:10.1016/j.cell.2007.07.044)

Carmeliet P 2003 Angiogenesis in health and disease. Nature Medicine 9 653-660. (doi:10.1038/nm0603-653)

Carmeliet P 2005 VEGF as a key mediator of angiogenesis in cancer. Oncology 69 4-10. (doi:10.1159/000088478)

Choi H, Chun YS, Kim SW, Kim MS \& Park JW 2006 Curcumin inhibits hypoxia-inducible factor-1 by degrading aryl hydrocarbon receptor nuclear translocator: a mechanism of tumor growth inhibition. Molecular Pharmacology 70 1664-1671. (doi:10.1124/mol.106.025817)

Colao A \& Savastano S 2011 Medical treatment of prolactinomas. Nature Reviews. Endocrinology 7 267-278. (doi:10.1038/nrendo.2011.37)

Ebert BL \& Bunn HF 1999 Regulation of the erythropoietin gene. Blood 94 1864-1877.

Farnoud MR, Kujas M, Derome P, Racadot J, Peillon F \& Li JY 1994 Interactions between normal and tumoral tissues at the boundary of human pituitary adenomas. Virchows Archiv: an International Journal of Pathology $\mathbf{4 2 4}$ $75-82$.

Ferrara N 2004 Vascular endothelial growth factor: basic science and clinical progress. Endocrine Reviews 25 581-611. (doi:10.1210/er.2003-0027)

Giustina A, Bronstein MD, Casanueva FF, Chanson P, Ghigo E, Ho KK, Klibanski A, Lamberts S, Trainer P \& Melmed S 2011 Current management practices for acromegaly: an international survey. Pituitary 14 125-133. (doi:10.1007/s11102-010-0269-9)

Gloddek J, Pagotto U, Paez-Pereda M, Arzt E, Stalla GK \& Renner U 1999 Pituitary adenylate cyclase-activating polypeptide, interleukin-6 and glucocorticoids regulate the release of vascular endothelial growth factor in pituitary folliculostellate cells. Journal of Endocrinology 160 483-490. (doi:10. 1677/joe.0.1600483)

Gospodarowicz D, Abraham JA \& Schilling J 1989 Isolation and characterization of a vascular cell mitogen produced by pituitary-derived folliculo stellate cells. PNAS 6 7311-7315. (doi:10.1073/pnas.86.19.7311)
Gupta SC, Kim JH, Prasad S \& Aggarwal BB 2010 Regulation of survival, proliferation, invasion, angiogenesis, and metastasis of tumor cells through modulation of inflammatory pathways by nutraceuticals. Cancer and Metastasis Reviews 29 405-434. (doi:10.1007/s10555-010-9235-2)

Gupta SC, Prasad S, Kim JH, Patchva S, Webb LJ, Priyardasini IK \& Aggarwal BB 2011 Multitargeting by curcumin as revealed by molecular interaction studies. Natural Product Reports 28 1937-1955. (doi:10.1039/c1np00051a)

Harris AL 2002 Hypoxia - a key regulatory factor in tumour growth. Nature Reviews. Cancer 2 38-47. (doi:10.1038/nrc704)

Hickey MM \& Simon MC 2006 Regulation of angiogenesis by hypoxia and hypoxia-inducible factors. Current Topics in Developmental Biology $\mathbf{7 6}$ 217-257.

Hori S, Hayashi N, Fukuoda J, Kurimoto M, Hamada H, Miyajima K, Nagai S \& Endo S 2009 Folliculostellate cell tumor in the pituitary gland. Neuropathology 29 78-80. (doi:10.1111/j.1440-1789.2008.00921.x)

Iwaki T, Kondo A, Takeshita I, Nakagaki H, Kitamura K \& Tateishi J 1986 Proliferating potential of folliculo-stellate cells in human pituitary adenomas. Immunohistochemical and electron microscopic analysis. Acta Neuropathologica 71 233-242. (doi:10.1007/BF00688045)

Jung HJ, Kim JH, Shim JS \& Kwon HJ 2010 A novel $\mathrm{Ca}^{2+} /$ calmodulin antagonist $\mathrm{HBC}$ inhibits angiogenesis and down-regulates hypoxia-inducible factor. Journal of Biological Chemistry 285 25867-25874. (doi:10.1074/jbc.M110.135632)

Kim K, Yoshida D \& Teramoto A 2005 Expression of hypoxia-inducible factor $1 \alpha$ and vascular endothelial growth factor in pituitary adenomas. Endocrine Pathology 16 115-121. (doi:10.1385/EP:16:2:115)

Kunnumakkara AB, Anand P \& Aggarwal BB 2008 Curcumin inhibits proliferation, invasion, angiogenesis and metastasis of different cancers through interaction with multiple cell signaling proteins. Cancer Letters 269 199-225. (doi:10.1016/j.canlet.2008.03.009)

Lafont C, Desarmenien MG, Cassou M, Molino F, Lecoq J, Hodson D, Lacampagne A, Mennessier G, El Yandouzi T, Carmignac D et al. 2010 Cellular in vivo imaging reveals coordinated regulation of pituitary microcirculation and GH cell network function. PNAS 107 4465-4470. (doi:10.1073/pnas.0902599107)

Lloyd RV, Scheithauer BW, Kuroki T, Vidal S, Kovacs K \& Stefaneanu L 1999 Vascular endothelial growth factor (VEGF) expression in human pituitary adenomas and carcinomas. Endocrine Pathology 10 229-235. (doi:10.1007/ BF02738884)

Lohrer P, Gloddek J, Hopfner U, Losa M, Uhl E, Pagotto U, Stalla GK \& Renner U 2001 Vascular endothelial growth factor production and regulation in rodent and human pituitary tumor cells in vitro. Neuroendocrinology 7 95-105. (doi:10.1159/000054675)

Masson N \& Ratcliffe PJ 2003 HIF prolyl and asparaginyl hydroxylases in the biological response to intracellular $\mathrm{O}(2)$ levels. Journal of Cell Science $\mathbf{1 1 6}$ 3041-3049. (doi:10.1242/jcs.00655)

Melmed S 2011 Pathogenesis of pituitary tumors. Nature Reviews. Endocrinology 7 257-266. (doi:10.1038/nrendo.2011.40)

Miller M, Chen S, Woodliff J \& Kansra S 2008 Curcumin (diferuloylmethane) inhibits cell proliferation, induces apoptosis, and decreases hormone levels and secretion in pituitary tumor cells. Endocrinology 149 4158-4167. (doi:10.1210/en.2007-1760)

Nagasawa H 1983 The in vitro and in vivo effects of dimethyl sulfoxide on the pituitary secretion of growth hormone and prolactin in mice. Annals of the New York Academy of Sciences 411 34-42. (doi:10.1111/j.1749-6632.1983. tb47283.x)

Onofri C, Theodoropoulou M, Losa M, Uhl E, Lange M, Arzt E, Stalla GK \& Renner U 2006 Localization of vascular endothelial growth factor (VEGF) receptors in normal and adenomatous pituitaries: detection of a nonendothelial function of VEGF in pituitary tumours. Journal of Endocrinology 191 249-261. (doi:10.1677/joe.1.06992)

Pagotto U, Arzberger T, Theodoropoulou M, Grübler Y, Pantaloni C, Saeger W, Losa M, Journot L, Stalla GK \& Spengler D 2000 The expression of the antiproliferative gene ZAC is lost or highly reduced in non-functioning pituitary adenomas. Cancer Research 60 6794-6799.

Perez-Castro C, Renner U, Haedo MR, Stalla GK \& Arzt E 2012 Cellular and molecular specificity of pituitary gland physiology. Physiological Reviews $\mathbf{9 2}$ 1-38. (doi:10.1152/physrev.00003.2011) 
Raverot G, Sturm N, de Fraipont F, Muller M, Salenave S, Caron P, Chabre O, Chanson P, Cortet-Rudelli C, Assaker R et al. 2010 Temozolomide treatment in aggressive pituitary tumors and pituitary carcinomas: a French multicenter experience. Journal of Clinical Endocrinology and Metabolism 95 4592-4599. (doi:10.1210/jc.2010-0644)

Renner U, Arzberger T, Pagotto U, Leingruber S, Uhl E, Müller A, Lange M, Weindl A \& Stalla GK 1998 Heterogeneous dopamine D2 receptor subtype messenger ribonucleic acid expression in clinically non-functioning pituitary adenomas. Journal of Clinical Endocrinology and Metabolism $\mathbf{8 3}$ 1368-1375. (doi:10.1210/jc.83.4.1368)

Renner U, Lohrer P, Schaaf L, Feirer M, Schmitt K, Onofri C, Arzt E \& Stalla GK 2002 Transforming growth factor- $\beta$ stimulates vascular endothelial growth factor production by folliculostellate pituitary cells. Endocrinology 143 3759-3765. (doi:10.1210/en.2002-220283)

Renner U, Paez-Pereda M, Arzt E \& Stalla GK 2004 Growth factors and cytokines: function and molecular regulation in pituitary adenomas. Frontiers of Hormone Research 32 96-109.

Saeger W, Lüdecke DK, Buchfelder M, Fahlbusch R, Quabbe HJ \& Petersenn S 2007 Pathohistological classification of pituitary tumors: 10 years of experience with the German Pituitary Tumor Registry. European Journal of Endocrinology 156 203-216. (doi:10.1530/eje.1.02326)

Santos NC, Figueira-Coelho J, Martins-Silva J \& Saldanha C 2003 Multidisciplinary utilization of dimethyl sulfoxide: pharmacological, cellular, and molecular aspects. Biochemical Pharmacology 65 1035-1041. (doi:10.1016/S0006-2952(03)00002-9)

Schaaf C, Shan B, Buchfelder M, Losa M, Kreutzer J, Rachinger W, Stalla GK, Schilling T, Arzt E, Perone MJ et al. 2009 Curcumin acts as antitumorigenic and hormone-suppressive agent in murine and human pituitary tumour cells in vitro and in vivo. Endocrine-Related Cancer 16 1339-1350. (doi:10.1677/ERC-09-0129)

Schaaf C, Shan B, Onofri C, Stalla GK, Arzt E, Schilling T, Perone MJ \& Renner U 2010 Curcumin inhibits the growth, induces apoptosis and modulates the function of pituitary folliculostellate cells. Neuroendocrinology 91 200-210. (doi:10.1159/000287236)

Shahani K, Swaminathan SK, Freeman D, Blum A, Ma L \& Panyam J 2010 Injectable sustained release microparticles of curcumin: a new concept for cancer prevention. Cancer Research 70 4443-4452. (doi:10.1158/00085472.CAN-09-4362)

Shan B, Gerez J, Haedo M, Fuertes M, Theodoropoulou M, Buchfelder M, Losa M, Stalla GK, Arzt E \& Renner U 2012 RSUME is implicated in HIF-1-induced VEGFA production in pituitary tumour cells. EndocrineRelated Cancer 19 13-27. (doi:10.1530/ERC-11-0211)

Shehzad A, Wahid F \& Lee YS 2010 Curcumin in cancer prevention: molecular targets, pharmacokinetics, bioavailability, and clinical targets. Archiv der Pharmazie 9 489-499. (doi:10.1002/ardp.200900319)
Shih SC \& Claffey KP 2001 Role of AP-1 and HIF-1 transcription factors in TGF- $\beta$ activation of VEGF expression. Growth Factors 19 19-34. (doi:10.3109/08977190109001073)

Ströfer M, Jelkmann W \& Depping R 2011 Curcumin decreases survival of Hep3B liver and MCF-7 breast cancer cells. The role of HIF. Strahlentherapie und Onkologie 187 393-400. (doi:10.1007/s00066-011-2248-0)

Thomas SL, Zhong D, Zhou W, Malik S, Liotta D, Snyder JP, Hamel E \& Giannakakou P 2008 EF24, a novel curcumin analog, disrupts the microtubule cytoskeleton and inhibits HIF-1. Cell Cycle 7 2409-2417.

Turner HE, Nagy Z, Gatter KC, Esiri MM, Harris AL \& Wass J 2000 Angiogenesis in pituitary adenomas and the normal pituitary gland. Journal of Clinical Endocrinology and Metabolism 85 1159-1162. (doi:10.1210/ jc.85.3.1159)

Viacava P, Gasperi M, Acerbi G, Manetti L, Cecconi E, Bonadio AG, Naccarato AG, Acerbi F, Parenti G, Lupi I et al. 2003 Microvascular density and vascular endothelial growth factor expression in normal pituitary tissue and pituitary adenomas. Journal of Endocrinological Investigation 26 23-28.

Vidal S, Horvath E, Kovacs K, Kuroki T, Lloyd RV \& Scheithauer BW 2003 Expression of hypoxia-inducible factor- $1 \alpha$ (HIF-1 $\alpha$ ) in pituitary tumours. Histology and Histopathology 18 679-686.

Wahl O, Oswald M, Tretzel L, Herres E, Arend J \& Efferth T 2011 Inhibition of tumor angiogenesis by antibodies, synthetic small molecules and natural products. Current Medicinal Chemistry 18 3136-3155. (doi:10.2174/ $092986711796391570)$

Webb JD, Coleman ML \& Pugh CW 2009 Hypoxia, hypoxia-inducible factors (HIF), HIF hydroxylases and oxygen sensing. Cellular and Molecular Life Sciences 66 3539-3554. (doi:10.1007/s00018-009-0147-7)

Wei W \& Yu XD 2007 Hypoxia-inducible factors: cross-talk between their protein stability and protein degradation. Cancer Letters 257 145-156. (doi:10.1016/j.canlet.2007.08.009)

Yadav VR \& Aggarwal BB 2011 Curcumin: a component of the golden spice, targets multiple angiogenic pathways. Cancer Biology \& Therapy $11236-241$. (doi:10.4161/cbt.11.2.14405)

Yuan Y, Hilliard G, Ferguson T \& Millhorn DE 2003 Cobalt inhibits the interaction between hypoxia-inducible factor- $\alpha$ and von Hippel-Lindau protein by direct binding to hypoxia-inducible factor- $\alpha$. Journal of Biological Chemistry 278 15911-15916. (doi:10.1074/jbc.M300463200)

Received in final form 22 June 2012

Accepted 27 June 2012

Made available online as an Accepted Preprint 27 June 2012 